\title{
Geografski termini in frazeologija
}

\author{
Mojca Žagar Karer
}

IZVLEČEK: Geografija je veda o naravnih in družbenih pojavih, torej o človekovem neposrednem okolju. Zato ni nenavadno, da se geografski termini pojavljajo tudi v frazemih. Izhajali smo iz terminov, ki so zbrani v Geografskem terminološkem slovarju (2005). Do frazeološkega gradiva smo prišli s pomočjo besedilnega korpusa FidaPLUS, upoštevali pa smo tudi SSKJ. Frazeme smo razvrstili v dve skupini, $v$ prvi so tisti, katerih sestavina je primarno geografski termin, v drugi pa tisti, katerih sestavina je termin, skupen več strokam. Obravnavali smo tudi skupino frazemov, ki vsebujejo zemljepisno ime.

ABSTRACT: Geography is a discipline dealing with natural and social phenomena, and therefore with man's immediate environment. It is therefore not unusual for geographical terms also to appear in idioms. This article is based on terms collected in the Geografski terminološki slovar (Dictionary of Geographical Terms, 2005). Idiomatic material was obtained using the FidaPLUS text corpus, and the Standard Slovenian Dictionary (SSKJ) was also taken into account. The idioms were sorted into two groups: those with a primarily geographical term as component, and those with a term shared by several disciplines as a component. A group of idioms containing a geographical name was also examined.

\section{Uvod}

V prispevku se bomo ukvarjali s frazemi, pri katerih je vsaj ena sestavina geografski termin. ${ }^{1}$ Geografijo smo izbrali, ker se ukvarja s preučevanjem človekovega neposrednega okolja in pri tem vključuje tako naravne kot tudi družbene vidike. Da bi lahko začeli s preučevanjem frazeologizacije, smo najprej potrebovali nabor terminov geografske stroke. Načeloma je pojmovni sistem stroke najbolj urejeno in

1 Prispevek je nastal na podlagi seminarske naloge pri podiplomskem študijskem predmetu Poglavja iz frazeologije pod mentorstvom red. prof. dr. Erike Kržišnik v šolskem letu 2005/2006. 
pregledno predstavljen $\mathrm{v}$ terminoloških slovarjih, zato smo pregledali Geografski terminološki slovar (2005) - v nadaljevanju GTS - z 8922 iztočnicami. Prav tako smo upoštevali 406 primerov s kvalifikatorjem geogr. iz SSKJ.

Temeljno gradivno osnovo za preučevanje frazeologije predstavljajo različna besedila, zato smo za pridobivanje frazeološkega gradiva uporabili referenčni korpus FidaPLUS. Iskanje po besedilih v neelektronski obliki se po učinkovitosti namreč ne more primerjati s pregledovanjem zadetkov po korpusu. E. Kržišnik (1996, 136-139) pri pomagalih za ugotavljanje »pravilnosti« frazeoloških tvorb poleg besedilnega gradiva in presoje rojenih govorcev navaja tudi splošne in frazeološke slovarje. ${ }^{2}$ Pri obravnavi frazemov z geografsko sestavino smo, kljub temu da je izhodišče predstavljalo besedilno gradivo iz korpusa, upoštevali tudi SSKJ. Enaka metoda je bila že uporabljena na gradivu iz fizikalne terminologije (Žagar 2005, 35-48), zato smo lahko primerjali posamezne ugotovitve.

\section{Geografija in Geografski terminološki slovar}

Geografija je v GTS opredeljena kot 'veda o vsestranski povezanosti, prepletenosti, soodvisnosti naravnih in družbenih pojavov, procesov na Zemljinem površju, ki kot celota ustvarjajo regionalno strukturo, pokrajinsko podobo'. Gre torej za kompleksno vedo, kar je vidno tudi pri področjih, ki jih obsega GTS: agrarna geografija, biogeografija, demogeografija, geografija krasa, geografija naselij, geografija prometa, geografija turizma, geomorfologija, hidrogeografija, industrijska geografija, kartografija, klimatogeografija, matematična geografija, pedogeografija, planiranje, pokrajinska ekologija, politična geografija, splošna geografija in varstvo okolja. V slovarju je zaradi večje preglednosti vsakemu terminu pripisano tudi ožje področje znotraj geografije.

Danes se geografija deli na fizično geografijo, ki združuje panoge, ki se ukvarjajo s fizičnim okoljem, in družbeno geografijo, ki preučuje družbene sestavine okolja. Dele zemeljskega površja celovito preučuje obča geografija. Zaradi spoznanja, da je geosfera proizvod naravnih in antropogenih sil je sodobna geografija most med naravoslovnimi in družboslovnimi vedami. (Enciklopedija Slovenije 1989, 192.)

\section{Frazeologizacija}

Frazeologizacija, tj. proces, $\mathrm{v}$ katerem nastanejo frazemi, je $\mathrm{v}$ nekaterih primerih povezana s procesom determinologizacije, torej s prehodom termina iz znanstvenih besedil v besedila, ki so namenjena širši javnosti (Žagar 2005, 35). Pri tem lahko osnovne pomenske sestavine termina ostanejo nespremenjene (delna determinologizacija) ali pa leksem dobi nov pomen (popolna determinologizacija). Primer delne determinologizacije s področja geografije bi bil recimo termin delta, primer popolne

2 Frazeološkega slovarja Slovenci še nimamo, v posameznih primerih pa si lahko pomagamo s poskusnim zvezkom Frazeološkega slovarja slovenskega jezika (Keber, 2003). 
determinologizacije pa obzorje v pomenu 'obseg izobrazbe, razgledanosti, znanja' (2. pomen po SSKJ).

O frazeologizaciji v zvezi z izterminološkimi frazemi piše J. Skladaná (2005, 313-317) - opredeli jo kot dinamični proces, pri katerem iz terminov nastanejo frazemi. V prispevku analizira nekaj frazemov, kot so postaviti koga/kaj na pranger, imeti (pri kom) kaj na rovašu itd., pri katerih je termin sestavina, ki je danes arhaizem in živi le še $\mathrm{v}$ frazeologiji. Tak primer najdemo tudi $\mathrm{v}$ gradivu iz fizikalne terminologije, tj. dati/postaviti kaj pod drobnogled (Žagar 2005, 46). Tudi E. Kržišnik $(1990,61,62)$ v obširni predstavitvi monografije Dragane Mršević-Radović: Frazeološke glagolsko-imeničke sintagme u savremenom srpsko-hrvatskom jeziku (Beograd, 1987) piše o tem, da je, če hočemo poznati konkretno motivacijsko izhodišče frazema, ob sinhroni analizi smiselno pritegniti tudi diahrono.

Omenimo, da se jezikoslovci ukvarjajo tudi z defrazeologizacijo (Ripka 2005, 298), to je proces, vezan zlasti na narečno terminologijo, pri katerem iz frazemov nastanejo termini. Gre predvsem za imena rastlin, živali ipd., Ripka $(2005,302)$ med drugim navaja primer kozja brada, ki poleg proste besedne zveze ('brada koze') in delno metaforične oznake moške brade ('brada kot pri kozi') označuje tudi ime rastline (bot. Tragopogon). V SSKJ pri iztočnici brada v terminološkem gnezdu najdemo: bot. travniška kozja brada 'travniška rastlina z bledo rumenim koškom in ozkimi listi, Tragopogon pratensis'. Termini, motivirani z metaforo (dobra misel, babje pšeno, carski rez itd.), bi si zaslužili posebno obravnavo.

\subsection{Frazeologizacija in geografski termini}

Termini so glede na izrazno podobo lahko večbesedni ali enobesedni. Večbesedni termin lahko v splošni rabi dobi nov pomen (v stroki še naprej funkcionira kot termin) in tako postane del frazeologije ${ }^{3}$ iz geografske (in sorodne) terminologije preideta $\mathrm{v}$ frazeologijo npr. ledena doba 'slabi odnosi' in dodana vrednost 'pozitiven dodatek, prednost'.4

Veliko pogosteje pa determinologizirani geografski termin predstavlja le eno sestavino frazema, npr. otoplitev odnosov 'vnovična vzpostavitev dobrih odnosov', črna celina 'Afrika', izgubiti kompas 'izgubiti občutek za pravo smer, za realno stanje'.

Glede na to, da je geografija most med naravoslovnimi in družboslovnimi vedami in da se ukvarja s človekovim neposrednim okoljem, ni presenetljivo, da so termini, ki se pojavljajo v frazemih, zelo različni. Nekateri so splošno geografski (npr. zemljevid, celina), drugi so vezani tudi na ekologijo (npr. gnojnica), astronomijo (npr. luna), ekonomijo (dodana vrednost), meteorologijo (npr. vihar) itd. Zato

3 O terminoloških zvezah, ki se nespremenjene, a z novim pomenom, uporabljajo v frazeologiji, piše Ž. Fink $(2005,61)$, pri tem navaja primere, kot so skupni imenovalec (iz matematike), verižna reakcija (iz fizike) ...

4 Terminov iz fizikalne terminologije, ki so dobili nov, frazeološki pomen je nekoliko več: črna luknja 'kjer vse izgine brez sledu' in 'skrivnostno dogajanje, stanje', kratek stik 'nesporazum', verižna reakcija 'vrsta povezanih dogodkov, ki sledijo izhodiščnemu', zorni kot ' izhodišče, osnova za presojanje česa' in zvezda stalnica 'kar/kdor je ves čas prisotno, ves čas enako v ospredju' (Žagar 2005, 46). 
smo jih razvrstili v dve skupini. V prvi so taki, ki vsebujejo primarno geografske termine, v drugi pa taki, ki vsebujejo izraze, ki so hkrati termini na področju geografije in $v$ drugih vedah. ${ }^{5}$

Seveda je ta razvrstitev le ena od mogočih. Izkazalo se je, da je gradivo zelo raznoliko in da včasih ne moremo vedeti, ali se termin determinologiziral in frazeologiziral iz geografije ali iz katere druge vede.

Veliko geografskih terminov je nastalo s terminologizacijo, torej tako, da je bil leksemu iz splošne leksike pripisan še terminološki pomen. Mogoče bi bilo obravnavati še tretjo skupino, kamor bi uvrstili frazeme, ki vsebujejo terminologiziran geografski termin. Gre za zelo splošne lekseme, kot so dom, mrak, svet, dan, noč itd., ki imajo v geografiji natančneje definiran pomen (dom je po GTS recimo 'geogr. nas. bivališče in drugi spremljajoči objekti, ki sestavljajo formalno in funkcijsko celoto', po SSKJ pa '1. prostor, hiša, kjer kdo stalno živi, od koder izhaja 2. navadno s prilastkom stavba, urejena za določen namen 3. knjiž. kmečka hiša, navadno z gospodarskimi poslopji 4. posestvo, domačija 5. posvetovalno ali zakonodajno telo, ki zastopa določen sloj ali ima določeno funkcijo'). Toda obravnava teh frazemov bi presegla namen (in obseg) tega prispevka. Bolj relevantno se zdi izpostaviti posebno skupino frazemov, ki vsebujejo zemljepisno ime (glej razdelek 3.2!), čeprav zemljepisna imena sicer ne sodijo med geografske termine v ožjem smislu.

Primeri rabe frazema $\mathrm{v}$ besedilu in podatki o številu zadetkov s frazeološkim pomenom so iz korpusa FidaPLUS. Na tem mestu je treba opozoriti, da včasih iz sobesedila ni bilo mogoče z gotovostjo določiti, ali gre za dobesedni ali frazeološki pomen, zato navedeni številski podatki kljub ročnemu pregledovanju vseh zadetkov niso povsem natančni. ${ }^{6}$ Uporabljali smo tudi za frazeologijo še vedno pomemben SSKJ. Kljub temu pa so številski podatki lahko koristen podatek v smislu približne ponazoritve pogostosti frazema, posameznih variantnih sestavin ipd. Frazemom so dodane tudi terminološke razlage terminov iz GTS.

\subsubsection{V izhodišču geografski termini}

$\mathrm{V}$ tem razdelku so obravnavani frazemi, ki imajo sestavino iz primarno geografske terminologije. Termini so urejeni po abecednem vrstnem redu.

\section{[1] Celina}

Celina je po GTS '1. geomorf. velika, sklenjena kopenska gmota na Zemljinem površju, ki jo z vseh strani obdajajo oceani ali robna morja 2. geomorf. velika, sklenjena kopenska gmota na Zemljinem površju, ločena od druge celine z morji, tudi z obsežnejšim gorovjem, veliko reko ali kopensko ožino'. Frazem črna celina (583 zadetkov v korpusu FidaPLUS) se zaradi barve kože večine tamkajšnjih prebivalcev

5 V vsaki vedi se del izrazja prekriva s tistim v drugih vedah, bodisi si od njih izposoja termine (ki jim potem nekoliko modificira pomen ali pa jih uporablja $\mathrm{v}$ istem pomenu) bodisi uporablja izrazno enake lekseme, ki imajo v različnih vedah povsem različen pomen.

${ }^{6}$ Lahko bi navedli tudi število vseh pojavitev besedne zveze, vendar ta podatek ne pove veliko. Pri frazemu črna celina bi lahko na primer zapisali, da so vsi zadetki v korpusu (583) frazeološki, pri frazemu odkriti Ameriko pa, da je vseh zadetkov 197, od tega je 107 frazeoloških, ostali pa so v povezavi s Krištofom Kolumbom ali drugimi srednjeveškimi pomorščaki. Razlika v številu nefrazeoloških in frazeoloških pojavitev v teh primerih za status frazema ni relevantna. 
uporablja v pomenu 'Afrika', v SSKJ ga najdemo kot pomenski odtenek pri iztočnici celina (dežele na črni celini 'v Afriki'). ${ }^{7}$ Primer:

Na potovanju po petih afriških državah se bo ameriški predsednik George W.

Bush soočil z žalostno podobo črne celine, ki so jo opustošili državljanske

vojne, revščina, pomanjkanje hrane in epidemije. (Mag, 2. 8. 2006))

Našli smo tudi 68 zadetkov, kjer je sestavina celina nadomeščena z njenim, prav tako geografskim, sinonimom kontinent. V SSKJ se črni kontinent nahaja $\mathrm{V}$ frazeološkem gnezdu pri iztočnici črn: publ. črni kontinent 'Afrika' (vsaj dodati bi bilo treba tudi črno celino, ki je po korpusnih podatkih bistveno pogostejša), pa tudi kot pomenski odtenek pri iztočnici kontinent. Primer:

Južnoafričan J. M. Coetzee (1940) je eden najbolj izrazitih pisateljev črnega

kontinenta, a slovenskim bralcem je bolj malo znan. (Delo, 28. 3. 2001)

Zanimivo je, da poleg črne celine v korpusu najdemo tudi zeleno celino v pomenu 'Južna Amerika' (37 zadetkov) in 'Avstralija' ( 9 zadetkov, večinoma povezanih s teniškim turnirjem Australian open). Na nastanek te besedne zveze (le pogojno bi jo lahko označili za frazem, saj nima vedno enakega pomena) je verjetno vplival frazem črna celina, le da se $\mathrm{v}$ tem primeru zelena barva nanaša na barvo površja celine, npr.:

Argentinski nogometaš Carlos Tevez je bil po izboru urugvajskega časnika El Pais že tretjič izbran za najboljšega igralca Južne Amerike, za najboljšega igralca zelene celine, ki igra v tujini, pa brazilski superzvezdnik v dresu španske Barcelone Ronaldinho. (Žurnal, 3. 8. 2006)

Hingisova je v Hongkongu celo grozila z možnim bojkotom turnirja v Avstraliji, če nagradnega sklada za moške in ženske tudi na zeleni celini naposled ne bodo izenačili. (Delo, 10. 1. 2000)

V zvezi z zapisom te zveze omenimo, da se v korpusu večkrat pojavi tudi zapis z veliko začetnico (Zelena celina). V tem primeru bi lahko šlo za nadomestno lastno ime, ki ga Toporišič v Enciklopediji slovenskega jezika $(1992,115)$ definira kot »Lastnoimensko poimenovanje na podlagi zamenjave (metonimije), npr. Otok nam. Velika Britanija, Rusija nam. ZSSR, Zaliv nam. Perzijski zaliv (ali Arabski zaliv), Vsemogočni nam. Bog, Devica nam. Marija.« Tudi v Slovenskem pravopisu (2001, 201) - dalje SP 01 - v slovarčku izrazja najdemo razlago za nadomestno ime: »ime, ki zamenjuje navadno uradno ime, npr. Otok za Velika Britanija; Prerok za Mohamed «. ${ }^{8}$ Iz primerov bi lahko sklepali, da gre vedno za enobesedno zamenjavo, toda v Enciklopediji slovenskega jezika $(1992,115)$ pri razlagi za nadomestno ime najdemo tudi primer slovenska prestolnica namesto Ljubljana. ${ }^{9}$ Kaj je torej nadome-

7 Frazem črna celina v pomenu 'Afrika' navaja tudi Keber $(2003,31,32)$ v poskusnem snopiču frazeološkega slovarja. Ima kvalifikator publicistično, po izvoru je metafora, ki se nanaša na črnsko prebivalstvo v Afriki, kar velja tudi za izraz črna Afrika. Sopomenka črne celine je afriška celina (v korpusu je pojavi 362-krat).

8 V slovarskem delu SP 01 ima Otok recimo kvalifikator publ., Prerok pa se sploh ne pojavi kot iztočnica. Na drugi strani pa imata npr. Zaliv in Rusija kvalifikator zem. $i$.

9 Bi morali zgled, glede na to, da zamenjuje lastno (zemljepisno) ime, pisati z veliko začetnico? 
stno lastno ime? Le enobesedna metonimična zamenjava ali vsaka (stalna) besedna zveza, ki lahko nadomešča lastno ime? $\mathrm{V}$ tem primeru bi poleg Zelene celine $\mathrm{v}$ to kategorijo uvrstili tudi Črno celino ipd. ${ }^{10} \mathrm{Zdi}$ se, da je opredelitev nadomestnega imena v Enciklopediji slovenskega jezika in predvsem v SP 01 preohlapna, saj dopušča različne interpretacije nadomestnega imena in $\mathrm{s}$ tem povzroča neenotnost $\mathrm{v}$ pisanju velike oz. male začetnice.

O tem, da je barva (kože prevladujočega prebivalstva oz. površja) pomembna sestavina frazema črna celina, govori podatek, da smo našli tudi besedno zvezo bela celina v pomenu 'Antarktika' (7 zadetkov).

Če se bo Zemlja še segrevala, obstaja nevarnost, da se bo ledena skorja zahodne Antarktike stalila in povzročila katastrofalne poplave. Raziskovalci ozračja lahko dokažejo, da se je bela celina najmanj enkrat v svoji zgodovini že delno stopila. (Delo, 1. 8. 2001)

Bolj pogost je frazem peta celina, ki označuje Avstralijo (150 zadetkov), npr.: Po lanskih poletnih olimpijskih igrah v Sydneyju je na peti celini ilegalno ostalo kar 60 udeležencev, med katerimi je polovica športnikov. (Dnevnik, 25. 4. 2001)

Našli smo tudi 3 primere, ko Avstralijo označuje besedna zveza sedma celina in 5 primerov, ko je Avstralija šesta celina, npr.:

Ameriška košarkarska reprezentanca po nedavni tekmi proti Avstraliji, ki so jo virtuozi iz lige NBA dobili z 89:64, ni več tako priljubljena med ljubitelji košarke na sedmi celini. (Delo 11. 9. 2000);

Tony Lenko je migracijski agent $\mathrm{v}$ Avstraliji - Rojakom pomaga pri urejanju dokumentov za selitev na šesto celino. (Delo, 1. 10. 2003)

Šesta celina in sedma celina (za razliko od ustaljene pete celine s 150 zadetki) seveda nista frazema, dokazujeta pa, da je štetje celin precej poljubno oz. da števnik ne pomeni vedno štetja. Sorodna frazema sta šesti čut in sedma umetnost - v obeh primerih gre za dodatek (čutov je pet, torej je šesti dodatni, nekaj posebnega; sedma umetnost je dodana šestim srednjeveškim umetnostim).

Zelo pogost pa je frazem stara celina $\mathrm{v}$ pomenu 'Evropa' (4537 zadetkov). Frazem izhaja iz kulturno-političnega pomena Evrope v zgodovini, predvsem v srednjem veku, ko so raziskovalci iz Evrope odkrivali nove celine, ${ }^{11}$ npr.:

Kakor je slišati, so v Moskvi sklenili odgovoriti na ameriško odločitev s pozivom evropskim državam, naj v sodelovanju z Rusijo vzpostavijo podoben raketni sistem tudi za obrambo stare celine. (Dnevnik, 2. 2. 1999)

Kot nasprotje stari celini je nastal frazem nova celina v pomenu 'Amerika' (124 zadetkov). Očitno je bila za Evropejce najpomembnejša nova celina prav Amerika,

${ }^{10}$ Zanimivo je, da pri črni celini nismo našli niti enega zapisa z veliko začetnico, zato pa jih je bilo kar nekaj pri stari celini in novi celini.

${ }^{11}$ Frazem stara celina v pomenu 'Evropa' navaja tudi Keber $(2003,31,32)$ v poskusnem snopiču frazeološkega slovarja. Ima kvalifikator publicistično in pojasnilo, da je Evropa s stališča evropskih raziskovalcev drugih celin upravičeno poimenovana kot stara celina. Avtor ji nasproti postavi novi svet in zeleni kontinent. Sopomenka stare celine je evropska celina (v korpusu najdemo 463 zadetkov). 
saj se nova celina vedno uporablja za Ameriko (natančneje za Severno Ameriko, zlasti za ZDA), ne pa za kakšno drugo celino, recimo Avstralijo. Možno je tudi, da je na novo celino vplival frazem novi svet $\mathrm{v}$ istem pomenu (v SSKJ novi svet $\mathrm{v}$ pomenu 'Amerika' najdemo v frazeološkem gnezdu pri iztočnicah nov in svet, tako kot črni kontinent ima tudi ta kvalifikator $p u b l$.). Npr.:

Svobodomiselni krogi so namreč prepričani, da je treba tudi v tem primeru, čeprav ima večina Američanov Walkerja za krivega, spoštovati tista merila človekovih pravic, ki so na novi celini veljala do 11. septembra, zdaj pa bi jih radi nekateri desničarji močno omejili. (Dnevnik, 17. 1. 2002)

Skupini frazemov, ki je povezana z zgodovinskim osvajanjem novih ozemelj: stara celina, nova celina, novi svet se pridružuje tudi frazem odkriti Ameriko (obravnavan je v razdelku 3.2). Tudi pri frazemih s sestavino iz fizike (Žagar 2005, 46) se izločijo frazemi, ki so med seboj povezani, tak primer je skupina frazemov, kjer se kot sestavina pojavi merska enota (8 primerov, npr. na tone, niti za milimeter, do grama (natančno) itd.).

\section{[2] Dolina}

Dolina je po GTS '1. geomorf. podolgovata, vsaj na eni strani odprta globel na Zemljinem površju, ki nastane zlasti zaradi rečne erozije, lahko pa jo preoblikujejo ledeniki, korozija, veter 2. geomorf., ljud., na krasu nižji svet 3. geogr. krasa, mednarodno $\rightarrow$ vrtača'. Solzna dolina v pomenu 'kraj trpljenja' vsebuje geografsko prvino dolina, sicer pa je izbiblični frazem. V korpusu se pojavi 93-krat, najdemo ga tudi v SSKJ, v frazeološkem gnezdu pri iztočnicah dolina in solzen (ekspr. ta svet je solzna dolina 'kraj trpljenja, težav'), npr.:

In ko se še bend imenuje Smrt v Vegasu, se zdi, da je poslušalčeva usoda za naslednjo uro zapečatena. Smrt, groza in obup. Ena sama solzna dolina. (Delo, 15. 1. 2000)

\section{[3] Džungla}

Termin džungla GTS pojasnjuje tako: '1. biogeogr. težko prehoden tropski deževni gozd na Indijski podcelini in Indokitajskem polotoku 2. biogeogr. gozd na močvirnih območjih Indijske podceline in Indokitajskega polotoka 3. biogeogr. zamočvirjeno območje ob vznožju Himalaje med Nepalom in Asamom, ki ga poraščajo trava, bambus in ločje 4. biogeogr. gosto zarasel rob tropskega gozda ob reki 5 . biogeogr. neustr. $\rightarrow$ tropski deževni gozd'. Frazem betonska džungla (116 zadetkov) pomeni 'mesto', pri čemer je poudarjena značilnost mest, da veliko njihovih prebivalcev živi v velikih (betonskih) blokovskih naseljih. Frazem ima v večini primerov iz korpusa negativno konotacijo, tako je tudi v spodnjem primeru:

Maribor je precej glasno in štorasto mesto, a daleč od tega, da bi bil nekakšna

betonska džungla. V njem je, hvala bogu, še zmeraj veliko zelenja in najbrž ga ni naselja, v katerem te zjutraj ne bi zbudilo ptičje petje. (Večer, 21. 5. 2000)

\section{[4] Era}

Pri terminu era GTS s kazalko usmerja na termin zemeljski vek, ki pomeni 'geomorf. geološko obdobje, ki se deli na periode'. Epoha ${ }^{12}$ pa je po GTS 'geomorf.

${ }^{12}$ Zanimivo je, da je izvor besede era latinski: iz poznolat. aera, èra 'štetje časa od kakega določenega trenutka' in določeno število, računska postavka' (Snoj 1997, 118), izvor 
geološko obdobje, ki sestavlja periodo'. V korpusu najdemo 162 zadetkov za frazem nova era v pomenu 'novo obdobje'. Obstaja tudi njegova varianta z geografskim terminom epoha, tj. nova epoha (14 zadetkov) v istem pomenu. Primera:

$\mathrm{Ob}$ tem se je zavzel za široko podporo dokumentu v parlamentu, saj, kot je dejal, ustava začenja novo ero $v$ Evropi. (Dnevnik, 12. 1. 2005)

In drugič, kar je najpomembnejše, vključuje spoznanje, da je tretje tisočletje nova epoha ne samo zaradi globalizacije in nove ekonomije, ampak predvsem zaradi pomena znanja. (Delo, 26. 5. 2001)

To, da je pomen frazema enak, čeprav imajo terminološke sestavine povsem različen pomen, kaže na popolno desemantizacijo terminoloških prvin. Tudi pri frazemih, katerih sestavina je fizikalni termin (Žagar 2005, 35-48), se pojavljajo primeri, kjer je ena sestavina lahko nadomeščena $\mathrm{z}$ drugo sestavino, ki je prav tako fizikalni termin (biti s kom na isti valovni dolžini/frekvenci, skozi prizmo/optiko česa, niti sekunde/minute, $v$ sekundi/minuti). Enako ugotavlja za frazem (obrniti se/ spremeniti se/...) za 180/360 stopinj tudi Ž. Fink $(2005,68)$, saj je frazeološki pomen v obeh primerih enak ('popolnoma, čisto') - pa čeprav pomeni obrat za 180 stopinj nekaj drugega kot obrat za 360 stopinj (pri katerem se znajdemo na isti točki).

\section{[5] Gora}

GTS goro opredeljuje tako: '1. geomorf. velika, masivna, navadno manj razčlenjena vzpetina, višja od griča ali hriba 2. geogr. krasa visok kup v kraški jami nakopičenega gradiva, največkrat skalovja, čez katerega lahko vodi jamska pot 3. agr. geogr., ljud. prvotna planina na obrobju gozdnate vzpetine s poznejšo trajno naselitvijo, npr. Gora nad Vipavsko dolino, Gora nad Sodražico 4. agr. geogr., ljud. na Dolenjskem $\rightarrow$ vinograd 5. geomorf., ljud. razgledna vzpetina z romarsko cerkvijo, npr. Šmarna gora, Gora Oljka'. V zvezi z goro bomo obravnavali 3 frazeme. Najpogostejši je (biti) naše gore list $\mathrm{v}$ pomenu '(biti) našega (tj. slovenskega) rodu' (101 zadetek), najdemo ga tudi v SSKJ (v frazeološkem gnezdu pri iztočnicah gora in list s kvalifikatorjem ekspr.). Npr.:

Nihče sicer ne bo vedel, da je bil Plečnik naše gore list, a bodo vsaj spoznali velikega arhitekta. (Mladina, 31. 5. 1997)

Frazem za devetimi gorami (153 zadetkov) v pomenu 'daleč stran' se navezuje na pravljice. Primer:

A8, ki je izginil izpred hiše v Šmartnem pod Šmarno goro, pa je verjetno res

že za devetimi gorami. (Delo, 14. 2. 2004)

Pri frazemu velik kot gora (30 zadetkov), ki pomeni 'zelo velik', pa je izposta-

besede epoha pa grški: iz gr. epokhē 'položaj zvezd, določen trenutek' (Snoj 1997, 118). Danes sta besedi sopomenki (po SSKJ: 'omejeno trajanje z razmerami, okoliščinami, stvarnostjo vred; doba') - med različnima terminoma (oz. vsebinama terminov) se je torej v geografiji vzpostavila razločevalnost tako, da so enemu pripisali izraz latinskega, za drugemu pa grškega izvora. V zvezi z determinologizacijo pa je že bilo opozorjeno, da $\mathrm{v}$ primerih, ko so termini latinskega oz. grškega izvora s sinhronega vidika ne moremo reči, ali je leksem v splošni jezik (v našem primeru kot sestavina frazema) prišel preko (v našem primeru geografske) stroke ali je ta pomen ves čas soobstajal s terminološkim. V fizikalni terminologiji so taki primeri vakuum, absorpcija, konstanta, resonanca in turbulenca. (Žagar 2005, 41.) 
vljena lastnost gore, da je velika. V SSKJ je frazem zabeležen v ilustrativnem gradivu pri iztočnici velik. Primer:

Njen šofer, grob in velik kot gora, sicer pa vdan, ji je sledil korak za korakom.

(Dnevnik, 28. 6. 2002)

\section{[6] Katastrofa}

Katastrofa je v GTS pojasnjena kot '1. spl. geogr. izreden dogodek, huda nesreča, ki povzroči izjemno veliko razdejanje in številne žrtve 2. spl. geogr. težko predvidljivo dogajanje $\mathrm{v}$ naravi, npr. poplave, potresi, nastalo tudi zaradi človekovega neustreznega poseganja $\mathrm{v}$ okolje, ki z veliko močjo v kratkem času zelo spremeni naravno in antropogeno okolje ter ogrozi zdravje, življenje velikega števila ljudi, drugih organizmov'. Frazem nacionalna katastrofa v pomenu 'dogodek, neprijeten za ves narod' (162 zadetkov) ima, podobno kot betonska džungla, negativno konotacijo. Večinoma je uporabljen ironično, saj je opisovani dogodek le redko blizu katastrofi v njenem običajnem pomenu.

Če bi Američani izgubili deset ali dvajset tisoč sinov edincev, bi bila prava nacionalna katastrofa, rodbine tretjega sveta lahko $\mathrm{v}$ boj preprosto pošljejo drugega, tretjega ali petega sina. (Delo, 28. 6. 2002)

\section{[7] Kompas}

Na področje kartografije spada tudi termin kompas, po GTS 'kart. priprava z magnetno iglo za ugotavljanje magnetnega severa in posredno s tem določanje strani neba'. Frazem izgubiti kompas v pomenu 'izgubiti občutek za pravo smer, za realno stanje' (189 zadetkov) se, glede na zadetke v korpusu, uporablja zlasti v besedilih, ki se ukvarjajo s politično tematiko. Na primer:

Imamo vlado, ki nima strategije, ki je izgubila kompas in ne zna oceniti gospodarskih gibanj niti za prihodnjih pet mesecev, kaj šele za prihodnji dve leti. (Delo, 14. 5. 2002)

\section{[8] Ledena doba}

Ledena doba ima v GTS naslednjo razlago '1. klimatogeogr., geomorf. obdobje v Zemljini geološki zgodovini, za katero je značilno večkratno zaporedje ohladitev s poledenitvami in krajših vmesnih otoplitev 2. klimatogeogr., geomorf. vsako od več hladnejših obdobij pleistocena, v mlajšem pleistocenu po alpski klasifikaciji donavska kot najstarejša, mindelska, günška, riška in würmska poledenitev kot najmlajša'. V veliki večini od 1327 zadetkov za termin ledena doba je ta uporabljen v geografskem pomenu ali pa gre za lastno ime (animirani film Ledena doba), včasih pa se pojavi tudi v prenesenem pomenu, in sicer v pomenu 'slabo stanje, slabi odnosi'. To je povezano s pogostejšim frazemom otoplitev odnosov (glej št. $11 \mathrm{v}$ tem razdelku!) in leksemom ledišče v pomenu 'najnižja točka', ki sta prav tako vezana na besedila množičnih medijev. Primer:

.../Z/unanji minister Joschka Fischer pa je po nočnih telefonskih pogovorih z ruskim kolegom Igorjem Ivanovom zagotovil, da Nemčiji in Zahodu kljub očitni zaostritvi v odnosih z Moskvo ne grozi nova ledena doba. (Delo, 26.

\section{1999)}

\section{[9] Morje}

GTS morje opisuje kot 'hidgeogr. robni del oceana, bolj ali manj ločen od njega z deli kopnega, otoki, podvodnimi vzpetinami'. Morje je tudi sestavina frazema 
kaplja $v$ morje $v$ pomenu 'majhna, nepomembna stvar' (352 zadetkov). V SSKJ je frazem uporabljen v razširjenem zgledu $\mathrm{v}$ frazeološkem gnezdu pri iztočnicah kaplja in morje (pomoč je zalegla toliko kot kaplja v morje 'nič; zelo malo'). Primer:

Dominik prejema od centra za socialno delo borih 13 tisočakov pomoči, kar pa je kaplja v morje ob vseh potrebah in dejstvu, da sta oba starša ostala brez zaposlitve. (Večer, 30. 3. 2001)

\section{[10] Oaza}

Termin oaza, po GTS pomeni '1. biogeogr. območje v puščavi, kjer zadostna količina razpoložljive talne vode omogoča rast kulturnih in naravnih rastlin 2. agr. geogr. zaokrožen kompleks namakanih obdelovalnih zemljišč znotraj izrazito sušnih območij'. V frazeologiji pa oazo najdemo kot sestavino frazema oaza miru (446 zadetkov) 'kraj, ki se od okolice razlikuje po ugodnem, umirjenem vzdušju'. Primer:

Ljudje so prijazni, Polzela je oaza miru, odlično pa so me sprejeli tudi soigralci in trener," pa je povedal Kanadčan, rojen v Romuniji. (Dnevnik, 23. 9. 2000)

V SSKJ najdemo pri iztočnici oaza tudi pomenski odtenek (knjiž., s prilastkom področje, kraj, ki se razlikuje od okolja po kaki lastnosti, zlasti pozitivni: redke kulturne oaze; oaza civilizacije, miru). Glede na zadetke v korpusu pa lahko rečemo, da je oaza miru stalna zveza s 446 zadetki, oaza civilizacije (2 zadetka) in kulturna oaza (1 zadetek) pa nista stalni zvezi.

\section{[11] Otoplitev}

Pri terminu otoplitev GTS usmerja na medledeno dobo 'klimatogeogr., geomorf. vsaka od toplejših dob med dvema ledenima dobama'. Frazem otoplitev odnosov 'vnovična vzpostavitev dobrih odnosov' (213 zadetkov) je izrazito vezan na jezik množičnih medijev, npr::

Iz Asadovih ust je to slišati kot otoplitev odnosov med državama, ki sta v sovražnih odnosih že več kot petdeset let. (Delo, 8. 7. 1999)

Tematsko se otoplitev odnosov neposredno navezuje na zvezo ledena doba in leksem ledišče v pomenu 'najnižja točka'. Ko odnosi dosežejo ledišče, nastopi ledena doba, kasneje pa se lahko odnosi otoplijo. Navedimo še primer za leksem ledišče v pomenu 'najnižja točka':

Odnosi med Londonom in Parizom so dosegli ledišče, ko je britanska vlada obtožila Francijo, da torpedira resolucijo OZN, ki je za pokoritev Iraka dovoljevala tudi uporabo vojaške sile. (Delo, 28. 1. 2004)

\section{[12] Plaz}

Po GTS je plaz '1. geomorf., hidgeogr. premikanje gmote kamenja, prsti, snega, ledu s polzenjem, plazenjem ali tokom, zlasti zaradi težnosti 2. geomorf. odkladnina, ki jo je odložil plaz 3. geomorf. vdolbina, območje, kjer se pogosto prožijo plazovi'; Frazem (vsuti/usuti/sprožiti se) plaz kritik/očitkov (268 zadetkov, od tega 136 zadetkov s sestavino kritika in $132 \mathrm{~s}$ sestavino očitki) se uporablja $\mathrm{v}$ pomenu 'veliko zaporednih kritik/očitkov'. Primera:

Nasprotno, nanj se je usul plaz kritik zaradi neuspešnih reform (državnih podjetij, finančnega sistema, stanovanj, zdravstva in izobraževanja), ki jih je začel izvajati, brž ko je prevzel premierski položaj. (Delo, 1. 12. 1999)

Pravi plaz očitkov se je sprožil na račun vlade, predvsem na okoljskega ministra Janeza Kopača ob obravnavi predloga opozicije, s katerim je ta želela 
pridobiti 160 milijonov tolarjev za ureditev vodotoka Dravinje. (Dnevnik, 1.

12. 2001)

\section{[13] Potok}

Potok je po GTS 'hidgeogr. v manjši in krajši strugi tekoča voda'. Frazem teči $v$ potokih (431 zadetkov) pomeni '(teči) v velikih količinah'. Veže se z dvema skupinama leksemov, v prvi so različne, predvsem telesne, tekočine (kri, solze, znoj ipd.), v drugi pa alkoholne pijače (pivo, vino, žganje itd.). Tudi v SSKJ najdemo pri iztočnici potok dva primera; $v$ ilustrativnem gradivu (ekspr. pot mu je $v$ potokih tekel po hrbtu) in $\mathrm{v}$ frazeološkem gnezdu: ekspr. vino je teklo $v$ potokih 'spili so zelo veliko vina'. Primera:

Po razglasitvi smrtne kazni je PKK že zagrozila, da bo kri v Turčiji tekla v potokih, zaostrili pa se bodo tudi odnosi med Turčijo in Evropsko unijo ter Svetom Evrope, še zlasti, če bo Turčija smrtno kazen nad Öcalanom tudi izvršila. (Delo, 30. 6. 1999)

Šlo je za pravo bosansko krčmo, v kateri je žganje teklo v potokih, kjer je pevka stopila na mizo in kjer pogosto niso spoštovali predpisov o delovnem času. (Večer, 3. 7. 1999)

\section{[14] Puščava}

Termin puščava GTS pojasnjuje z 'biogeogr., geomorf. redko poseljena pokrajina $v$ tropskem, subtropskem in zmernotoplem pasu, brez rastlinstva ali z zelo redkimi suholjubnimi rastlinami, prilagojenimi redkim, majhnim količinam padavin'. V zvezi s puščavo najdemo 2 frazema. Bolj pogost je glas vpijočega v puščavi (134 zadetkov), ki pomeni 'neuspešno prizadevanje, razširjanje kakega nazora'. Frazem je izbiblični, tako kot solzna dolina. Najdemo ga tudi v SSKJ pri iztočnicah glas, vpiti in puščava. Primer:

Upravičeno vprašanje, zakaj naši mlinarji, če meljejo cenejšo, uvoženo pšenico, ne znižajo cen moke, kruha in peciva, zato izzveni kot glas vpijočega $v$ puščavi. (Večer, 21. 7. 1999)

Drugi frazem je (potrebovati) kot puščava vodo/dež v pomenu 'zelo potrebovati'. V korpusu najdemo 7 zadetkov, od tega jih je $5 \mathrm{~s}$ sestavino voda, 2 pa s sestavino dež, npr.:

Kot puščava vodo potrebuje ta država sodoben kardiokirurški center, ki bi bil strokovno in organizacijsko povsem neodvisen od Kliničnega centra in bi mu tako predstavljal konkurenco. (Nedeljski dnevnik, 28. 7. 2002)

\section{[15] Zemljevid}

Termin zemljevid je v GTS opredeljen takole: '1. kart. navadno papir, platno z upodobitvijo Zemljinega površja, objektov na njem v pomanjšanem merilu 2. kart. papir, platno z geografskimi podatki o pojavih, stanjih, procesih'. Frazem (postaviti) na svetovni zemljevid (123 zadetkov) '(kaj) postati prepoznavno izven meja domovine' ima tudi varianto postaviti/vrisati/.. na zemljevid sveta (57 zadetkov). Pogosto se frazem uporablja v zvezi s prepoznavnostjo Slovenije kot države in njenih kulturnih, športnih ipd. dosežkov. Primera:

Irski step je na svetovni zemljevid postavil Michael Flatley, s sedemminutnim nastopom na prireditvi izbora za pesem Evrovizije leta 1994. (Delo, 5. 10. 2001)

Prvič, Bosanske basni Tomaža Lavriča so domačemu stripu letos prinesle 
prestižno mednarodno priznanje, ga postavile na zemljevid sveta in potrdile, da je o slovenskem stripu moč debatirati v tržni terminologiji. (Mladina, 7. 5. 1999)

\subsubsection{Termini v več strokah}

$\mathrm{V}$ ta razdelek smo uvrstili frazeme, ki vsebujejo kak termin, ki ni samo geografski, ampak se uporablja tudi v drugih strokah. Izločila se je tudi večja skupina frazemov, ki so vezani na vremenske pojave (glej razdelek 3.1.2.1!).

\section{[1] Dodana vrednost}

Termin dodana vrednost (GTS jo označuje kot 'spl. geogr. bruto vrednost proizvodnje, zmanjšana za vrednost proizvodov in storitev, ki jih proizvajalec porabi v proizvodnji in pri prodaji') je še bolj kot za geografijo pomemben za ekonomijo in sorodne vede. $\mathrm{V}$ frazeologijo je termin dodana vrednost $\mathrm{v}$ zadnjem času ${ }^{13}$ prišel v pomenu 'pozitiven dodatek, prednost'. ${ }^{14}$ Primera:

$\mathrm{Mi}$, naša politična koalicija, moramo do konca doumeti, da je slovenska manjšina kot vse manjšine dragocena in pomembna. Dodana vrednost, ki nam jo daje slovenska manjšina, mora biti res zaščitena. To mora naša stran razumeti, to je politično in kulturno pomembno. (Delo, 10. 4. 2001)

Zdaj se govori o konkretnih obveznostih iz člena št. 5 in golih elementih vojaškega prispevka, povedo diplomatski viri. Skratka, ocenjuje se dodana vrednost, ki bi jo morebitne nove članice pomenile za Nato. (Delo, 7. 4. 2001)

[2] Gnojnica

$\mathrm{Na}$ agronomijo pa je vezan termin gnojnica (po GTS 'agr. geogr. mešanica seča domačih živali z vodo in snovmi, ki nastanejo iz seča zaradi naravne presnove'). Frazem zlivati/polivati gnojnico (po kom/čem, na koga/kaj) ima pomen 'grobo obtoževati (koga), grdo govoriti (o kom)' (91 zadetkov). V SSKJ ga (v razširjeni obliki) najdemo v frazeološkem gnezdu pri iztočnici gnojnica (ekspr. drugega ne zna kot polivati z gnojnico 'grdo, nesramno govoriti o kom'). Pomensko se navezuje na leksem blatiti. Primer:

Po njem zlivajo gnojnico plemeniti Jelinčiči in Černjakov podmladek, ne mara ga bivši premier in mu ne zaupa sedanji. (Delo, 24. 2. 2003)

\section{[3] Luna}

S terminom luna, ki je v GTS opisan kot '1. mat. geogr. satelit planetov 2. mat. geogr. z veliko začetnico Zemljin satelit' se ukvarja tudi astronomija. V zvezi z luno smo našli 3 frazeme (vse tri najdemo tudi v SSKJ v frazeološkem gnezdu pri iztočnici luna). Najpogostejši je pasti z lune, ki pomeni 'nenavadno se obnašati' (61 zadetkov). Primer:

Mar ni na Škotskem tako, da vas pogledajo, kot da ste padli z lune, če $\mathrm{v}$ gostilni rečete, da bi radi viski, saj ga poznajo na tisoče vrst? (Mladina, 11. 6. 1995)

${ }^{13}$ Avtorica prispevka frazem pozna tudi iz govorjenega jezika.

${ }^{14}$ Ker je v korpusu za termin dodana vrednost zelo veliko zadetkov (9516), večina je vezanih na DDV, tj. davek na dodano vrednost, nismo prešteli vseh frazeoloških rab frazema. 
S frazemom pasti z lune je povezan s frazemom živeti na luni 'biti slabo obveščen o aktualnih dogodkih' (19 zadetkov), primer:

Toda slovensko notranje ministrstvo očitno živi na luni, ko misli, da razen

Slovenije ni več držav, in pri sestavljanju spiska nezaželenih oseb razmišlja le o slovenskih domačijskih interesih. (Mladina, 19.3. 1995)

V korpusu najdemo tudi 16 zadetkov za frazem lajati $v$ luno $v$ pomenu 'nemočno groziti', npr.:

Zaskrbljen pa ni zaradi opozicije, ki skoraj brezzoba laja v luno in čaka, da se iz Bruslja vrne Romano Prodi in jo spet združi, ampak zaradi sporov med prijatelji in zavezniki, ki se ne pustijo voditi, kakor bi bilo po volji njemu. (Delo, 2. 9. 2003)

\section{[4] Obrt}

Podobno kot dodana vrednost se tudi termin obrt uporablja na področju geografije, pa tudi gospodarstva, ekonomije. GTS ga opredeljuje takole: 'ind. geogr. gospodarska dejavnost, ki opravlja usluge ter z ročnim ali/in strojnim delom v manjših količinah predeluje surovine, polizdelke in proizvaja blago zlasti za osebno porabo'. V frazeologiji je obrt sestavina frazema najstarejša obrt v pomenu 'prostitucija' ${ }^{15}$ (347 zadetkov), primer:

V Italiji opravlja najstarejšo obrt 25 tisoč prostitutk iz držav izven EU, približno deset odstotkov jih je iz držav nekdanje Jugoslavije. (Primorske novice,

21. 8. 1998)

\subsubsection{Vremenski pojavi}

Ker se je pokazalo, da ima kar 15 frazemov sestavino s kakšnim vremenskim pojavom, smo se odločili, da bomo te frazeme obravnavali v posebnem podrazdel$\mathrm{ku}$. Termini, ki se pojavljajo v tej skupini frazemov imajo v GTS kvalifikator klimatogeografsko ${ }^{16}$, sicer pa so še najbolj povezani z meteorologijo. V uvodu Meteorološkega slovarja piše: »Stroka s tega področja je bila sprva opisna in tudi pri nas tesno povezana z zemljepisjem, pozneje (po prvi tretjini tega stoletja) pa je prešla $v$ fiziko atmosfere. V zadnjem času je meteorologija s svojimi potrebami pospešila razvoj nekaterih področij matematike in je z njo tesno povezana.« (Petkovšek in Leder 1990, 3). Opozoriti je treba, da gre pri vremenskih pojavih za pojme, ki se pogosto uporabljajo v splošnem jeziku, zato je njihova terminološkost danes bolj ali manj zabrisana.

[1] Dež

Dež je po GTS 'klimatogeogr. padavina v obliki kapelj s premerom več kot 0,5 mm'. V zvezi z dežjem smo našli 2 frazema. ${ }^{17}$ Pogostejši je (priti/iti ...) z dežja

${ }^{15} \mathrm{~V}$ zvezi s prostitucijo se tudi sicer uporablja veliko frazemov. Gre za tabuizirano področje in že pri hitrem pregledu besedil s to tematiko dobimo precej primerov, večinoma evfemizmov, npr. prijateljica noči, dekle na klic, prodajalka ljubezni, kupljivi užitki, javna hiša, spolne storitve, spolne usluge itd.

${ }^{16}$ Nekaj terminov s tem kvalifikatorjem je sicer obravnavanih že v razdelku 3.1 .1 (npr. ledena doba, otoplitev).

${ }^{17}$ Keber $(2003,35)$ v poskusnem snopiču frazeološkega slovarja navaja tudi frazem imeti lase (brke) [počesane, postrižene] na dež 'tako, da visijo in da so ravno prirezani', fra- 
pod kap v pomenu '(priti/iti ...) iz slabega na še slabše' (202 zadetka). V SSKJ se nahaja $\mathrm{v}$ frazeološkem gnezdu pri iztočnici dež (ekspr. priti z dežja pod kap 'iz ene neprijetnosti v drugo, še hujšo'). Primer:

Po napadu Nemčije na Rusijo je bilo vse težje in po enajstih mesecih sem se vrnil domov. A prišel sem $\boldsymbol{z}$ de pričakali Italijani s puškami. (Dolenjski list, maj 2002)

Frazem govoriti kot dež pa pomeni 'hitro, veliko govoriti' (30 zadetkov). V SSKJ ga najdemo v ilustrativnem gradivu pri iztočnici govoriti (govori kot dež 'hitro, veliko'). Npr.:

Vanna govori kot dež in nenadoma zmanjka časa. Če si mislil, da boš moral besede vleči iz mene, si se zmotil, čeblja in se ozira po izhodu. (Delo 30. 4. 1999)

\section{[2] Megla}

Megla po GTS pomeni 'klimatogeogr. drobne vodne kapljice ali ledeni kristali v prizemni zračni plasti, ki zmanjšajo vodoravno vidljivost pod 1 km'. V frazeologiji pa najdemo meglo $\mathrm{v} 2$ frazemih (oba frazema sta tudi v SSKJ, v frazeološkem gnezdu pri iztočnici megla); prvi je (kaj biti) zavito v meglo in pomeni 'kaj biti (še) neraziskano, nejasno' (258 zadetkov), primer:

Je pa res, da je marsikaj v zvezi z njim zavitega $v$ meglo, pač zaradi njegove izjemne sposobnosti, da še tako radovednemu in nadležnemu spraševalcu položi v ušesa le tisto, kar sam hoče povedati. (Delo, 3. 8. 1998)

Drugi frazem vleči se kot megla 'počasi, leno se premikati' ni tako pogost, $\mathrm{v}$ korpusu najdemo 23 zadetkov, npr.:

Inspiracija je nujna. So obdobja, ko se vlečeš kot megla, brez volje, in se ti vse zdi ponavljanje. Ob določenih spremembah, v dialogu, po kakšni razstavi, debati pa lahko dobiš navdih. (Delo, 5. 8. 2000)

\section{[3] Oblak}

Oblak GTS opredeljuje kot 'klimatogeogr. zgoščene vodne kapljice, ledeni kristalčki in drugi trdni delci, kot sklenjena koprena vidni v višjem ozračju'. Oblak smo našli v 3 frazemih (v SSKJ so vsi trije v frazeološkem gnezdu pri iztočnici oblak); (zidati) gradove v oblakih $\mathrm{v}$ pomenu '(načrtovati) nedosegljive, neizvedljive stvari' se v korpusu pojavi 306-krat (namesto zidati se lahko pojavi tudi glagol obljubiti, graditi ipd). Primer:

Bodite realni in ne zidajte gradov v oblakih, saj se vam lahko vse skupaj

prehitro poruši, kakor hiša iz kart. (Večer, 3. 6. 2000)

Nekaj nedosegljivega predstavljajo oblaki tudi v frazemu živeti v oblakih 'sanjariti' (70 zadetkov), npr.:

O sanjskem avtomobilu, ki bi ga izbiral, ne glede na funkcionalnost in ceno, nisem nikoli razmišljal, saj ne živim v oblakih. (Celjan, avgust 2002)

Frazem dvigniti oblak prahu pa pomeni 'povzročiti razburjenje' (8 zadetkov v korpusu):

Če je v zdravstvu kaj narobe, potem je to v Mariboru, natančneje v tukajšnji

zem najdemo tudi v SSKJ v frazeloškem gnezdu pri geslu dež, v korpusu pa ni nobenega zadetka. 
bolnišnici. Vsaj v javnosti tako izpade. Tudi če zboli vojak in to dvigne oblak prahu, ga pripeljejo umret v Maribor. (Večer, 29. 3. 2000)

\section{[4] Sneg}

GTS je sneg razložil z '1. klimatogeogr. padavina v obliki bolj ali manj sprijetih, različno oblikovanih ledenih kristalov, izjemoma zrn 2. klimatogeogr. $\rightarrow$ snežna odeja'. Glede na to, da se sneg hitro topi in da zapade vsako leto znova, ni nenavadno, da je nastal frazem ( $k$ ot za) lanski sneg s pomenom 'kar ni vredno pozornosti' (282 zadetkov), Zapisan je tudi v SSKJ, npr. v ilustrativnem gradivu pri iztočnici lanski (zame se briga, zanima kakor za lanski sneg 'nič'). Primer:

V teh pogovorih - zdaj vam to prosto povem, čeprav snemate -, se z direktorjem nismo pogovarjali o lanskem snegu, ampak o konkretni zadevi. (Delo, 27. 9. 1999)

\section{[5] Strela}

Strela je po GTS 'klimatogeogr. razelektritev ozračja med nevihto, ki povzroča bliskanje in grmenje'. V zvezi s strelo, ki je kratek, a dramatičen vremenski pojav, smo našli 2 frazema.

Pragmatični frazem gromska strela (109 zadetkov) se uporablja za podkrepitev trditve, na primer:

Gromska strela, je rekla. Še tri minute nisva v deželi, pa si že ujela moškega.

(Dnevnik, 4. 9. 2000)

Frazem kot strela z jasnega pa pomeni 'nenadoma, nepričakovano' (36 zadetkov), ${ }^{18}$ npr.:

Bila sem na pregledu pri doktorju Pavlovčiču, ki je potrdil, da sem zdrava,

potem pa me nekdo črta s seznama. To je bilo zame kot strela z jasnega.

(Mag, 2. 8. 2006)

V SSKJ najdemo oba frazema pri iztočnici strela, prvega pri 3. pomenu (3. ekspr., v medmetni rabi izraža [...] b) začudenje, presenečenje: gromska strela, kaj pa ti tukaj?), drugega pa v ilustrativnem gradivu pri 1. pomenu (novica je prišla kot strela z jasnega 'popolnoma nepričakovano').

\section{[6] Veter}

Veter je v GTS razložen s 'klimatogeogr. zaradi razlik v zračnem tlaku, temperaturi premikajoči se, gibajoči se zrak s hitrostjo več kot 2 bofora'. V frazeologiji pa je veter dobil svoje mesto $v 3$ frazemih (vse tri najdemo tudi v SSKJ v frazeološkem gnezdu pri iztočnici veter), najbolj pogost je frazem $z$ vseh vetrov v pomenu 'od vsepovsod' (1119 zadetkov), na primer:

Desettisoči aktivistov $\boldsymbol{z}$ vseh vetrov so se ta teden zbrali v Firencah na prvem

Evropskem socialnem forumu, ki skuša združiti pisano druščino več kot štiristo protiglobalizacijskih gibanj po vsej stari celini. (Dnevnik, 8. 11. 2002)

Drugi obravnavani frazem je nov veter v pomenu 'nov zagon, nova energija' (821 zadetkov), npr.:

S prihodom Matjaža Keka na mesto Prašnikarjevega pomočnika je v ekipi za-

${ }^{18}$ Frazem kot strela z jasnega $\mathrm{v}$ pomenu 'popolnoma nepričakovano' navaja tudi Keber $(2003,105,106)$ v poskusnem snopiču frazeološkega slovarja. Sopomenska primera je kakor bi treščilo z jasnega. 
vel nov veter. Treningi so dobili spremenjeno podobo, so precej bolj aktivni. (Delo, 21. 7. 1999)

Veter je tudi sestavina frazema, ki je sicer prišel iz literature, ${ }^{19} \mathrm{tj}$. boj/boriti se/... z mlini na veter (363 zadetkov) v pomenu 'spopad/spopadati se z namišljeno nevarnostjo', ${ }^{20}$ npr.:

Oba primera kažeta našo okoljsko (ne)osveščenost. Boj s takimi majhnimi smetišči se žal še vedno zdi boj $\boldsymbol{z}$ mlini na veter. Nastajajo vedno znova. (Večer, 9. 3. 2000)

Zavest o izvoru frazema je še vedno živa, saj se v zvezi s frazemom pogosto uporablja literarna oseba Don Kihot (tudi donkihotovski (boj) ipd.), primer:

Včasih se počutim kot Don Kihot, ki se bori z mlini na veter, pove drugi teden po izbruhu afere. (Mladina, 25. 7. 1993)

[7] Vihar

Vihar je po GTS opredeljen kot 'klimatogeogr. veter z jakostjo 8 boforov, ki lomi vejice in veje dreves'. Vihar je sestavina 2 frazemov. Frazem vihar v kozarcu vode pomeni 'veliko neupravičeno razburjenje' (106 zadetkov). V SSKJ ga najdemo v frazeološkem gnezdu pri iztočnicah vihar, kozarec in voda. Primer:

Razdor v prevaljskem občinskem odboru LDS, ki je po številu svetnikov tamkajšnja najmočnejša stranka, ni le vihar v kozarcu vode, marveč že resen zaplet. (Delo, 25. 10. 2002)

Frazem politični vihar pa označuje 'intenzivno, nemirno politično dogajanje' (72 zadetkov), na primer:

S pripombo, da lahko CDU za predvolilno kampanjo leta 2002 izbere katero koli temo, tudi priseljevanje, je sprožil politični vihar $\mathrm{v}$ državi, ki jo že neonacistični izgredi opozarjajo na latentni rasizem v lastnih vrstah. (Delo, 21. 10 2000)

\subsection{Pasji dnevi}

$\mathrm{V}$ tem podrazdelku si bomo ogledali termin pasji dnevi, ki v širšem smislu prav tako spada $\mathrm{k}$ vremenskim pojavom. V GTS so pasji dnevi opredeljeni takole: 'klimatogeogr. obdobje hude poletne vročine na koncu julija in v začetku avgusta'. Zvezo najdemo tudi v Meteorološkem slovarju (Petkovšek in Leder 1990), in sicer: '1. poljud. obdobje največje poletne vročine 2. po praktiki čas, ko je Sonce v znamenju Leva'; v Leksikonu CZ Geografija (Krušič 1985): 'klimatska singulariteta, vroči dnevi konec julija in v začetku avgusta; izraz izhaja iz starega Egipta in se ujema z zgodnjim vzhodom ozvezdja Psa na nebu v teh dnevih'; v leksikonu Geografija (Kladnik 2001): 'najbolj vroči dnevi v Evropi, ki so še posebno izraziti v Sredozemlju. Pojavljajo se julija in avgusta in imajo ime po času, ko je Sonce v ozvezdju psa'. Zanimivo je, da še najnatančneje omeji pasje dneve SSKJ (v frazeološkem gnezdu pri iztočnici pasji): 'čas od 23. julija do 23. avgusta', sledi pa še en pomen: ekspr. takrat smo imeli pasje dneve 'dneve hude vročine'. ${ }^{21}$ Ali to pomeni,

${ }^{19}$ M. Cervantes: Bistroumni plemič Don Kihot iz Manče.

${ }^{20}$ Frazem boj z mlini na veter 'spopadanje $\mathrm{z}$ namišljeno nevarnostjo' navaja tudi Keber $(2003,29)$ v poskusnem snopiču frazeološkega slovarja.

${ }^{21}$ Pasji dnevi se pojavijo še pri iztočnici dan kot pomenski odtenek pri 3. pomenu: ekspr. črni, pasji dnevi 'zelo neprijetni, hudi'. 
da imamo enkrat opraviti s frazemom ('obdobje hude poletne vročine'), drugič pa s terminom ('čas, ko je Sonce v ozvezdju Psa')? V prvem primeru bi sestavina pasji prinašala negativno konotacijo (poletna vročina, ki je huda, neprijetna), v drugem pa bi se nanašala čas, ko je Sonce v ozvezdju Psa. Gre za dve različni referenci, ki pa ponavadi sovpadeta (najhujša poletna vročina je pogosto ravno v času od 23. julija do 23. avgusta, ko je Sonce v ozvezdju Psa). Kot zanimivost omenimo, da se pasji dnevi pojavijo že v Cigaletovi Znanstveni terminologiji (1880), in sicer pri iztočnici Hund: 'astr. pes, veliki, mali; Hundstage, pasji dnevi.

Pasji dnevi v pomenu 'obdobje hude poletne vročine' se v korpusu pojavijo 472-krat, navedimo še primer:

Pred nami so pasji dnevi, ko je lahko zelo vroče, ni pa nobena redkost, če prav tedaj, denimo v Švici, pošteno sneži. (Nedeljski dnevnik, 20. 7. 2003)

\subsection{Frazeologizacija in zemljepisna imena}

Posebna skupina frazemov se izloči, če upoštevamo tudi zemljepisna lastna imena (in pridevnike, ki so iz njih izpeljani (španski, švicarski ...)) - to seveda niso geografski termini, so pa zemljepisna imena nedvomno povezana $\mathrm{z}$ geografijo $\mathrm{v}$ širšem smislu. ${ }^{22}$

Frazem španska vas ima pomen 'popolnoma neznana, nezanimiva stvar' (508 zadetkov), najdemo ga tudi v SSKJ, $v$ frazeološkem gnezdu pri iztočnicah španski in vas. ${ }^{23}$ Npr.:

Meja z Madžarsko je problem zasepredvsem zaradi madžarskih mejnih organov, ki jim je ažurnost pri opravljanju postopkov španska vas, je med drugim ugotovila komisija. (Dnevnik, 16. 10. 1999)

Ker so za Sibirijo značilne ekstremne zimske temperature, frazem sibirski mraz (49 zadetkov) označuje 'zelo hud mraz'. V SSKJ ga najdemo v ilustrativnem gradivu (kot pomenski odtenek) pri iztočnici sibirski (ekspr. bil je pravi sibirski mraz). Primer:

V prestolnici je takrat med dežjem padla tudi kakšna snežinka. Za Rim in okolico je bilo to dovolj, da so zaradi domnevnega sibirskega mraza nekateri lokalni veljaki v časnikih že zahtevali razglasitev stanja naravne katastrofe. (Delo, 23. 1. 2002)

Frazem kot švicarska ura (80 zadetkov) se uporablja v pomenu 'odlično, brez napak'. Švicarji so namreč znani po svojih kakovostnih, natančnih urah. Primer:

Ob trepljanju motorja je povedal, da se ga zadnjih 20 let še ni pritaknil in da teče kot švicarska ura. (Novi tednik, 27. 3. 1998)

Frazem odkriti Ameriko (107 zadetkov) v pomenu 'odkriti, povedati kaj novega'

${ }^{22}$ Tudi Ž. Fink $(2005,67)$ izpostavi izraze, ki niso pravi termini, so pa povezani z (v njenem primeru) naravoslovnimi vedami - za primer navede matematiko s frazemi, kot so sešteti ena in ena, (kaj biti) kot enkrat ena, (obrniti/spremeniti se) za 180/360 stopinj.

${ }^{23}$ Frazem navaja tudi Keber $(2003,113)$ v poskusnem snopiču frazeološkega slovarja in pojasnjuje, da izhaja iz nemškega für jmdn. spanische Dörfer sein, ki je nastal s križanjem dveh frazemov - das ist mir spanisch (nanaša se na španskega in nemškega kralja Karla V., ki je v nemških deželah uvajal nerazumljive španske običaje) in für jmdn. böhmische Dörfer sein (Nemcem so bila imena čeških vasi nerazumljiva). 
se tematsko navezuje na v razdelku 3.1.1 obravnavane frazeme stara celina in nova celina oz. novi svet. Odkriti Ameriko v SSKJ najdemo v frazeološkem gnezdu pri iztočnicah odkriti in Amerika (iron. misli, da bo odkril Ameriko 'kaj novega'). ${ }^{24}$ Primer:

Eden od diskutantov je, misleč, da je odkril Ameriko, opozoril, da hočejo slovenska podjetja $\mathrm{v}$ ZRJ v resnici izvažati svoje nekakovostno blago in da gre pri priznanju za interes tega lobija. (Mladina, 4. 12. 1995)

Frazem pravi Teksas 'nevarno področje z veliko kriminala' (4 zadetki), ${ }^{25}$ izhaja iz stereotipov, ki veljajo za ameriško zvezno državo Teksas (veliko umorov, kriminala nasploh). Zanimivo je, da že SSKJ navaja Teksas tudi kot občno ime: teksas 'žarg. kraj, lokal, ustanova, kjer vlada sila, nered'. Primer:

Kočevje je v povojnem obdobju veljalo za pravi Teksas. Še pred nekaj leti je bilo v letu dni na Kočevskem storjenih skoraj toliko umorov kot v vsej preostali Sloveniji skupaj. (Dolenjski list, oktober, 1994)

Frazem Zgornji Kašelj (20 zadetkov) pomeni 'nepomemben majhen kraj'. Kraj s takim imenom res obstaja (od središča Ljubljane je oddaljen približno 8 kilometrov), vprašanje pa je, zakaj je med vsemi majhnimi in nepomembnimi slovenskimi kraji ravno ta postal del frazeologije. Morda zaradi nenavadnega imena (bolezenski znaki niso običajna sestavina zemljepisnih imen) in dejstva, da obstajata tako Spodnji kot tudi Zgornji Kašelj (delitev vasi na zgornji in spodnji del je značilnost mnogih manjših slovenskih krajev). V spodnjem primeru torej ne gre za konkretni kraj Zgornji Kašelj, ampak za katerikoli nepomemben majhen kraj:

In vendar je Marko oblikoval grb, ki od osamosvojitve krasi zastavo in je kot simbolna podoba tako ponesrečen, da ga ne privoščim niti gasilskemu društvu v Zgornjem Kašlju. (Milan Dekleva: Pimlico, roman, 1998)

Tudi Spodnji Kašelj (17 zadetkov) se lahko rabi frazeološko, pomen pa je enak:

Kajti razžaljeni tožnik ni bil kak Janez Novak iz Spodnjega Kašlja, ampak je bil državni podsekretar, visoki državni uradnik. (Delo, 26. 5. 2001)

Za frazem (iti/oditi/...) v Canosso ${ }^{26} \mathrm{v}$ pomenu 'priznati podrejenost, se ponižati', v korpusu najdemo 23 zadetkov. Najdemo ga tudi v SSKJ. Prav tako je možna samostalniška oblika pot v Canosso (11 zadetkov), npr.:

Po tem cvetoberu vladnih pojasnil ostane sklep: naj vlada že kupi to preklicano letalo ali pa naj razdre pogodbo in gre v Canosso, le klovna naj več ne igra!

Leonid Brežnjev je avgusta 1968 (ob izbruhu žametne revolucije v Pragi) poklical Aleksandra Dubčka na zagovor v Moskvo. Dubček je odklonil pot v Canosso, delegaciji sta se srečali na meji. (Delo, 15. 3. 2003)

Podobno kot frazem iti $v$ Canosso ${ }^{27}$ ima izvor v zgodovinskem dogodku tudi

${ }^{24}$ Frazem odkriti Ameriko v pomenu 'odkriti kaj novega' navaja tudi Keber $(2003,26)$ v poskusnem snopiču frazeološkega slovarja. Frazem ima kvalifikator ironično.

${ }^{25}$ Avtorica prispevka frazem pozna iz govorjenega jezika.

${ }^{26}$ Po SSKJ je možen tudi zapis iti $v$ Kanoso, v korpusu je za ta zapis le en zadetek.

${ }^{27}$ Leta 1077 je nemški cesar Henrik IV. moral na tridnevno pot v Canosso, da bi prosil papeža Gregorja VII., ki ga je izobčil, za odpuščanje. 
frazem prestopiti/prekoračiti/... Rubikon ${ }^{28}$ (220 zadetkov) v pomenu 'storiti odločilno dejanje'. Primer:

Tudi predsednik Demokratične zveze Kosova dr. Ibrahim Rugova je prestopil

Rubikon, ko je šel v Beograd na pogovore z Miloševićem in ruskim patriarhom, ker ne zastopa stališč Kosova in njegovega ljudstva. (Delo, 17. 5. 1999)

V zvezi z zgodovinskimi dogodki omenimo še frazem videti se pri Filipih ${ }^{29}$ v pomenu 'imeti odločilen obračun, spopad', ki ga zabeleži že SSKJ, v korpusu pa sicer najdemo 21 zadetkov, ampak so vsi vezani na zgodovinski dogodek, torej v nobenem primeru ni rabljen $v$ frazeološkem pomenu. V SSKJ sta še dva frazema $z$ zemljepisnim imenom, za katera nismo našli sodobnih primerov, in sicer star. vodo $v$ Savo nositi 'opravljati nepotrebno, nekoristno delo' in iti v Rim v pomenu 'roditi'. 30

Bosna je dobila svoje mesto v pragmatičnem frazemu mirna Bosna, ki se uporablja kot podkrepitev trditve (55 zadetkov). Frazem najdemo tudi v SSKJ pri iztočnici Bosna (pog., ekspr., navadno kot podkrepitev, v zvezah: kar pusti vse skupaj, pa mirna Bosna 'saj je vseeno'; tako bo, kot sem rekel, in mirna Bosna 'o tem ne bomo več govorili'). Primer:

Reči je menda treba ljudstvu pojasniti, čeprav imamo vlado za to, da sama sprejema odločitve in jih požegna v parlamentu. Če se vlada ne strinja s poslanci, naj preprosto odstopi in mirna Bosna! (Delo, 5. 2. 2003)

Frazem Indija Koromandija vsebuje zemljepisno ime Indija, zraven pa še domišljijski dodatek Koromandija. Uporablja se v pomenu 'obljubljena dežela' (285 zadetkov). V SSKJ najdemo iztočnico Indija Koromandija v pomenu 'dežela, kjer je vsega dovolj, kjer je zelo dobro', primer:

Da se razumemo: Evropa ni Indija Koromandija. Čakajo nas težko delo in

številni problemi. (Mladina, 17. 5. 1997)

V zvezi z zemljepisnimi imeni omenimo, da se ta pojavljajo tudi v pregovorih, npr. Vse poti vodijo v Rim; Če greš na Dunaj, pusti trebuh zunaj; Nekaj je gnilega $v$ deželi danski (citat iz Shakespearovega Hamleta) itd.

Pri frazemih, katerih sestavina je zemljepisno lastno ime, se pojavlja tudi pravopisni problem pisave z veliko oz. malo začetnico. E. Kržišnik (2003, 233, 234) ugotavlja, da SP 01 zagovarja pisanje zgledov z zemljepisnim lastnim imenom z veliko začetnico (iti v Canosso, odkriti Ameriko itd.), toda hkrati se kot samostojna iztočnica pojavlja rubikon v pomenu 'meja, mejnik', iz česar lahko sklepamo, da bi sestavino rubikon $\mathrm{v}$ frazemu prekoračiti/prestopiti rubikon morali pisati z malo začetnico. ${ }^{31}$ Avtorica ugotavlja, da je tudi raba neenotna in da SP 01 tovrstno gradivo večinoma izpušča in $\mathrm{s}$ tem prepušča odločitev glede pisave $\mathrm{z}$ veliko oz. malo začetnico piscem.

Obravnavali smo 10 frazemov, ki vsebujejo zemljepisna imena oz. iz njih izpe-

${ }^{28} 49$ pr. n. št. je Cezar kljub prepovedi prestopil reko Rubikon in s tem začel državljansko vojno.

${ }^{29}$ Brutu je pred odločilno bitko pri Filipih leta 42. pr. n. št., v kateri je kasneje izgubil, zli duh rekel: Se vidiva pri Filipih! (in s tem napovedal končni obračun).

${ }^{30}$ Frazem avtorica prispevka sicer pozna iz govorjenega jezika.

${ }^{31} \mathrm{~V}$ korpusu najdemo 170 zapisov z veliko začetnico (Rubikon) in $50 \mathrm{z}$ malo (rubikon). 
ljane pridevnike. Torej so tudi zemljepisna imena postala del frazeologije, pa naj gre za lastnosti ali značilnosti posameznih držav oz. pokrajin - sibirski mraz (izjemen mraz), španska vas (oddaljenost (od nas), kot švicarska ura (kvaliteta izdelkov te države), pravi Teksas (veliko kriminala), Zgornji/Spodnji Kašelj (majhnost), mirna Bosna (politična) nemirnost); zgodovinske dogodke - iti v Canosso, prestopiti/prekoračiti Rubikon, odkriti Ameriko ali domišljijske dežele - Indija Koromandija.

\section{Zaključek}

Frazeme, ki vsebujejo sestavino iz geografske terminologije, smo razvrstili v dve skupini, v prvi so tisti, katerih sestavina je primarno geografski termin (npr. črna celina), v drugi pa tisti, katerih sestavina je termin, ki je skupen več strokam (npr. dodana vrednost). V drugi skupini predstavlja največjo podskupino 15 frazemov, katerih sestavina je kak vremenski pojav (npr. vihar, megla, strela ...) - kar kaže na to, da je bilo vreme vedno pomembna prvina človekovega okolja. V okviru vremenskih pojavov smo obravnavali tudi frazem pasji dnevi, pri katerem se križata dva pomena, terminološki ('obdobje, ko je Sonce v ozvezdju Psa') in frazeološki ('obdobje hude poletne vročine').

Frazeme z geografsko sestavino lahko združimo v več različnih skupin. Nekaj frazemov je povezanih tematsko (npr. odkrivanje novih ozemelj: stara celina, nova celina, novi svet (tudi odkriti Ameriko)) - pri frazemih s sestavino iz fizike pa se recimo izločijo frazemi, kjer se kot sestavina pojavi merska enota (npr. na tone, niti za milimeter, do grama (natančno) itd.)), pa tudi tako, da se isti determinologizirani termin pojavlja $\mathrm{v}$ več frazemih (npr. pasti z lune, živeti na luni in lajati $v$ luno). Nekateri frazemi imajo več variant, kjer se lahko menjuje prav geografska sestavina (npr. črna celina/kontinent, nova era/epoha). Pomen frazema ostaja enak, tudi če imajo terminološke sestavine povsem različen pomen, kar kaže na popolno desemantizacijo terminoloških prvin. Take primere smo opazili tudi pri frazemih, katerih sestavina je fizikalni termin (biti s kom na isti valovni dolžini/frekvenci, skozi prizmo/optiko česa, niti sekunde/minute, v sekundi/minuti).

Dodali smo še posebno skupino 10 frazemov, ki sicer ne vsebujejo geografskih terminov, so pa vseeno povezani z geografijo - vsebujejo namreč zemljepisno ime. Za frazeologijo so pomembne predvsem značilnosti oz. lastnosti posameznih držav ali pokrajin in zgodovinski dogodki.

V zvezi z zemljepisnimi imeni smo se dotaknili tudi problema ohlapnih meril SP 01 za nadomestna imena in pisave z veliko oz. malo začetnico lastnoimenske sestavine $\mathrm{v}$ frazemih, pri katerih je ena od sestavin zemljepisno lastno ime. 


\section{Viri in literatura}

Geografski terminološki slovar 2005, Ljubljana, Založba ZRC SAZU.

Keber, Janez, 2003, Frazeološki slovar slovenskega jezika: poskusni zvezek, Ljubljana, ZRC SAZU.

Korpus slovenskega jezika FidaPLUS: < http://www.fidaplus.net>.

Slovar slovenskega knjižnega jezika, Elektronska izdaja v. 1.0, 1998, Ljubljana, DZS.

Slovenski pravopis 2001, Ljubljana, Založba ZRC SAZU.

Cigale, Matej, 1880, Znanstvena terminologija: s posebnim ozirom na srednja učilišča, Ljubljana, Matica slovenska.

Enciklopedija Slovenije, 3. zv. (Eg-Hab) 1989, Ljubljana, Mladinska knjiga.

Fink, Željka, 2005, Frazeologija u prirodnim znanostima, prirodne znanosti u frazeologiji, Frazeologické štúdie IV, Bratislava, Veda 60-68.

Kladnik, Drago (prevod in priredba), 2001, Geografija, Tržič, Učila International (Zbirka Tematski leksikoni).

Krušič, Marjan (urednik), 1985, Geografija, Ljubljana, Cankarjeva založba (Leksikoni Cankarjeve založbe).

Kržišnik, Erika, 1990, Teoretično zanimiva knjiga iz frazeologije, SR 38/1, 57-64.

Kržišnik, Erika, 1996, Norma v frazeologiji in odstopi od nje v besedilih, $S R$ 44/2, 133-154.

Kržišnik, Erika, 2003, Frazeologija v Slovenskem pravopisu 01, SR 51/2, 221-239.

Petkovšek, Zdravko in Leder, Zvonka (gl. urednika), 1990, Meteorološki terminološki slovar, Ljubljana, ZRC SAZU in Društvo meteorologov Slovenije.

Ripka, Ivor, 2005, Od frazémy k termínu: Prenesené l'udové názvy rastlín, Frazeologické štúdie IV, Bratislava, Veda, 298-302.

Snoj, Marko, 1997, Slovenski etimološki slovar, Ljubljana, Mladinska knjiga (Zbirka Cicero).

Skladaná, Jana, 2005, V minulosti termíny, v súčasnosti frazémy, Frazeologické štúdie IV, Bratislava, Veda, 313-317.

Toporišič, Jože, 1992, Enciklopedija slovenskega jezika, Ljubljana, Cankarjeva založba (Leksikoni Cankarjeve založbe).

Žagar, Mojca, 2005, Determinologizacija (na primeru terminologije fizike), JiS $50 / 2,35-48$.

\section{Geographical Terms and Idioms}

Summary

This article is an attempt to collect and classify idioms in which at least one constituent is a geographical term. It is based on terms collected in the Geografski terminološki slovar (Dictionary of Geographical Terms, 2005), and the FidaPLUS text corpus was primarily relied upon as a material basis. The idioms were sorted into two groups: those with a primarily geographical term as component (e.g., črna celina 'the dark continent'), and those with a term shared by several disciplines as 
$4 \quad$ a component (e.g., dodana vrednost 'value added'). In the second group, the largest subgroup is represented by idioms whose component is some kind of weather phenomenon (e.g., vihar 'storm', megla 'fog', strela 'lightning', etc.). A group of idioms containing a geographical name was also examined (e.g., odkriti Ameriko 'to reinvent the wheel'). Idioms with a geographical constituent can be combined into several different groups. Some idioms are thematically linked (e.g., discovery of new territory: stara celina 'the old world', nova celina, novi svet 'the new world'), and sometimes the same term also appears in multiple idioms (e.g., pasti z lune 'to fall from the clouds', živeti na luni 'to have one's head in the clouds', and lajati v luno 'to make idle threats'). Certain idioms have multiple versions in which the geographical element itself may change (e.g., crna celina/kontinent 'the dark continent', nova era/epoha 'new age'). The meaning of the idiom remains the same even if the terminological elements have a completely different meaning, which points to the full de-semantization of the terminological elements.

Mojca Žagar Karer

Inštitut za slovenski jezik Frana Ramovša ZRC SAZU

Novi trg 2, 1000 Ljubljana

mzagar@zrc-sazu.si 